\section{REFLECTIONS ON NORTHERN ROCK}

A little over a year ago it would have been difficult to imagine the severity of the storm which was about to hit the banking markets in the United Kingdom (UK) and elsewhere. There had been reports of some banking problems in the United States and news stories about subprime lending difficulties were starting to emerge, but the growing liquidity freeze that was developing in the financial markets was to intensify to a degree which no one appears to have predicted.

In the UK the story has focused on the problems at Northern Rock, a little known mortgage bank which was not of particular systemic importance. Within the industry it had been seen as a rising star which had been growing at a particularly fast pace. The events of September 2007, which included the first run on a bank in the UK since 1878 (when there were runs on several banks as a result of the collapse of the City of Glasgow Bank), were quite astonishing. The last bank of any significance to get into financial difficulties in the UK was the merchant bank Barings in 1995. This received significant media attention but Barings was not considered to be systemically important and accordingly did not receive a bailout by the government. Instead it went into administration and was ultimately purchased by the Dutch bank ING. The Barings crisis was dealt with quickly using the existing corporate insolvency laws and the general view at the time was that the outcome was satisfactory. There were no calls for reform of the insolvency laws to introduce any special procedures for banks. Barings had been dealt with quickly and effectively at no cost to the British taxpayer.

How different it has been in the Northern Rock case. The serious financial problems at Northern Rock were reported by the BBC in September 2007, a day before an official statement was to have been made by the relevant authorities, and the run started. Another significant feature was that this was the first banking crisis to take place under the financial sector safety net which came into place in 1997 when responsibility for supervising banks was removed from the Bank of England to the newly created Financial Services Authority (FSA). This new megaregulator was to work in conjunction with the Treasury and the Bank of England on the basis of a memorandum of understanding.

Northern Rock's problems provided the first opportunity to see how the financial sector safety net would operate. It is beyond the scope of this editorial to set out in detail the events which took place but those who would like to find out more should read The Run on the Rock (a detailed report by the House of Commons Treasury Committee published in January 2008). In addition to concluding that none of the relevant parties come out of this well, it was also felt that there were serious shortcomings in the legal infrastructure. In particular the

\section{Articles}

Constitutionalism: an idea whose time has come and gone?

3

Fraud Act 2006: has it had any impact?

Institute News

\section{Articles (cont'd)}

Respecting family life

Nineteenth century defamation: was it a law of the press?

The Irish referendum on the Lisbon Treaty

lack of an appropriate vehicle for dealing with financially troubled banks and deficiencies in the system for protecting bank depositors were identified.

Northern Rock was subsequently nationalised in February 2008 after a failure to find a private sector purchaser. This was described by the authorities as a "temporary" measure but at this stage it is impossible to know just how temporary it is likely to be. However, the bank's business operations have been continuing to lose money and its asset base is continuing to shrink. A significant amount of the money advanced by the authorities to Northern Rock has been repaid but this appears to have been achieved by mortgage redemptions by those borrowers who have been able to refinance from other lenders. Effectively this means that Northern Rock is losing many of those borrowers whose mortgages are fully up to date and who have good credit ratings. Those who are in arrears with their mortgage repayments will not be in a position to refinance with other lenders and will presumably stay put. Northern Rock continues to operate in the market for deposits with the significant advantage over its competitors of a government guarantee. The bank is attracting deposits by offering relatively high interest rates with the public being aware that these deposits are fully backed by a government guarantee. This is certainly not popular with competitors.

So what will happen to Northern Rock? The intention is to return it, at some stage, either in whole or in part, to the private sector. What is less clear is whether the public funds used to bail it out will ever be repaid in full. Typically where public funds have been used for bank bailouts there tends to be a loss to the public purse and this may well prove to be the case with Northern Rock.

\section{WHERE TO FROM HERE?}

What has come out of the Northern Rock crisis? It has led to a series of consultations and reports and much 
discussion of all aspects of the workings of the financial sector safety net.

It has been recognised that there were many shortcomings. The FSA has been criticised for its approach to the regulation and supervision of Northern Rock; the Bank of England for its policy on emergency liquidity assistance; the Chancellor of the Exchequer and the Prime Minister for continuous indecision and failure to take action. All of the parties have been criticised for the poor quality of communications between them despite the memorandum of understanding that all were parties to. The compensation scheme for depositors has been found wanting. There were two specific weaknesses which exacerbated the run on Northern Rock. First, the level of cover was found to be insufficient and second, the delay in making compensations payments was unacceptable. The lack of a specific vehicle to deal with a financially distressed bank was also considered to be a weakness.

There will undoubtedly be new legislation in place within the relatively near future, and this will certainly include a special resolution regime as well as changes to the compensation scheme for bank depositors. There will also be clearer rules to ensure that the authorities work together more effectively with the responsibilities of each of the parties being carefully set out.

\section{SOME CONCLUDING THOUGHTS}

No doubt some good will come out of this. First, the regulatory culture will surely be stronger in the future. Second, banks will have to introduce more effective risk management procedures both in relation to lending policies and to funding their activities. Securitisation and "pass the parcel" techniques will be far more carefully scrutinised and controlled. Third, there will undoubtedly be clearer rules on who is to have responsibility for doing what, so that effective and timely action will hopefully be taken in future.

The recent series of consultations has been worthwhile and has provided the opportunity for a period of reflection. This has led not only to a rethink about the UK's legal framework for dealing with financially distressed banks but also to the whole issue of the financial sector safety net. That the system did not work as well as expected is not in dispute and it must work better in future if London is to continue to be one of the world's leading financial centres.

\section{Andrew Campbell}

Reader in International Banking and Finance Law, School of

Law, University of Leeds

E-mail: a.campbell@leeds.ac.uk 